\title{
Problems of the Management of Elderly Welfare in Thailand; the Subsistence Allowance
}

\author{
Thitirut CHANMAHA
}

\begin{abstract}
One of countries in the world approaching aging society is Thailand. It has been aging society since 2005 and it will be aged society in 2025 . Thailand has to confront the same problem with the other countries in the world from this situation. In addition, due to rapidly increasing of elderly population in Thailand, the elderly dependent are increased as well. For this reason, one of strategies set by Thai government in order to prepare for aging society is policy of the elderly subsistence allowance.

The purpose of this study was study the policy of the elderly welfare, particularly in subsistence allowance for the elderly through a documentary research. The result showed that problem encountered in this policy consists of two types; i) Problem from the elderly, ii) Problem of the policy. Problem of the elderly found that the elderly do not cooperate with the policy nor realise their right to receive the elderly subsistence allowance. Although, the elderly realise the right to receive the subsistence allowance, most of them do not submit their application within the time limit because of distance and complicated documentary process. The elderly do not receive the subsistence allowance from their representatives. Their relatives do not inform the death of the elderly to the authority. Regarding Problem of the policy found as follows: lack of publication of policy, lack of appropriate criterion to select the eligible elderly, payment exceeding the time limit and/or changing several times of payment method, and lack of responsible government sector.

Therefore, the recommendation for this policy is as follows: local sectors should have a power to stipulate criterion and to consider to select the eligible, make an payment of subsistence allowance within the time limit in every month and set up the community of the elderly to promote the elderly profession by support from government sectors in respect of health and welfare consult.
\end{abstract}

Keywords - Elderly, Welfare, Subsistence

\section{INTRODUCTION}

In the present time, the world population circumstances have been receiving attention, especially the constantly changing of the population structure which is becoming to the new structure called "Aging Society". As a member of global society, Thailand has also facing the crucial social structural changing by moving to the "Aging Society"

The proportion of the workable age and childhood population have been decreasing, it is because the constantly decreasing of birth and death rate of Thailand and approaching Thailand's average lifetime age more last long. This kind of situation which happened to Thailand is the same circumstances which have been happened in another country

Thitirut CHANMAHA, University of Bordeaux, France as well, the changing of the population structure; 'Aging Society'. This issue had been concerned and being paid more attention both nationally and globally due to a widespread impact on the macro level.

Thailand National Statistical Office has reported the elderly population situation in Thailand, which calculated people with age 60 and above, has steadily increased year by year and Thailand has become "Aging Society" since 2005.

As in 2014, Thailand elderly population had 10,014,705 people which consisted of 4,514,815 males and 5,499,890 females. From 65,124,716 people which consisted of 31,999,008 males and 33,125,708 females. Thailand elderly population was $15.38 \%$ compared to the whole population. (survey every 3 years) In addition, The United Nations has described the country's population which proportion of population aged 60 and over accounted for over $10 \%$ of the population, and aged 65 years and over reached over $7 \%$ of the country's population will consider that the country has entered the aging society and will be completely Aged Society when the proportion of the population aged 60 years reached $20 \%$, and aged 65 years and over reached $14 \%$. Apart from that statistic, Thailand essentially required and provided Elderly Social welfare Management.

The main question of this research is how to manage the elderly welfare in Thailand, in addition; problems, solutions and recommendations. Moreover, the results of this study to further develop strategies and policies on the elderly welfare management in the Thailand.

\section{OBJECTIVE}

The objective of this study is to study elderly social welfare management in Thailand, to analyze problem, and provide elderly social welfare management solution in Thailand.

\section{Methodology}

This study has adopted documentary research method by focusing the 133 studies in Thailand from The Office of the Higher Education Commission; Thailand library integrated system database. In addition, Central Region of Thailand has the largest quantity of elderly population.

\section{SOCIAL WELFARE FOR THE ELDERLY IN THAILAND}

Social Welfare for the Elderly in Thailand is divided into 4 parts as follows:

1. Social Insurance is public safeguard program for living and protection of employee from lack of income after retirement. State of society has changed and the elderly receive 
less support from their family; additionally, chronic illness requires high medical expense.

Social Insurance in Thailand consists of the following funds:

1) Social Security Fund. In case of pension for Old-age person for the purpose of saving for employee in private company by Ministry of Labour;

2) Government Pension Fund (GPF) is a mandatory saving scheme of government officer according to the law;

3) Government Permanent Employee Registered Provident Fund (GPEF). Benefit is pension of employee and money that members contributed to the fund which returns by the government;

4) Provident Fund is deemed to be the beginning of a voluntary fund;

5) Retirement Mutual Fund (RMF) is a voluntary saving for high capital people;

6) Private School Headmaster and Teacher Fund is a mandatory saving scheme set up by Ministry of Education;

7) Thaweesuk Fund is Money saving special fund named Thaweesuk set up by Bank for Agriculture and Agricultural Cooperatives to support a saving for agriculturists and their family;

8) Community Welfare Fund is Money saving special fund in community level to create a security and better life for community member set up by Community Organizations Development Institute (public organization); and

9) Old-Age Fund is a voluntary saving for old-age persons set up by Ministry of Finance.

2. Public Assistance is free-of-charge social work for people who cannot help themselves and disadvantage and helpless people, consists of as follows:

1) Subsistence allowance for Elderly is free-of-chargepayment;

2) Venerable Elderly Fund set up by Office of Welfare Promotion, Protection and Empowerment of Vulnerable Elderly;

3) Legal consult and helping from maltreatment and abandonment for the elderly victims by Ministry of Justice;

4) Exempt from the entrance fee to government places for the elderly by Ministry of Transport and Ministry of Natural Resources and Environment;

5) Support for transportation fee based on appropriation by Ministry of Transport.

3. Social Service. A service system to respond basic human needs consist of 5 aspects of services as follows:

1) Health - National Health Security.

2) Education - Non-Formal and Informal Education.

3) Residence - Free-of-Charge Shelter and Caring.

4) Working and Income - the Elderly Welfare Fund

5) Social Service and Recreation - Elderly Club

4. Help from public sector is social welfare management by other groups of people such as, the social welfare management covering Birth, Old, Illness and Death.

\section{POLICY OF SUbSISTENCE ALlOWANCE}

\section{A. Figures and Tables}

Subsistence allowance for the elderly has been implementing as the one of most important policy demonstrated by the Department of Public Welfare since 1993 pursuant the Cabinet Decision on 3 March 1992 during the period of the Prime Minister Anand Panyarachun, which approved the Department of Public Welfare to proceed the project of the subsistence allowance for the elderly to allocate the budget concerning the subsistence allowance to help the elderly who suffered from many aspects of trouble. In this regard, Ministry of Finance approved continuously the disbursement for this project as the subsistence allowance for each elderly at the rate of 200 Baht per month through their life. The first year, the only 20,000 elderly throughout the country received this subsistence allowance.

After the Constitution of the Kingdom of Thailand, Buddhist Era 2540 (1997) was effective; moreover, the government during such period focused on the policy of decentralization to local organization, the government transferred the project of the subsistence allowance for the elderly to Local Administrative Organization namely, Provincial Administrative Organization, Municipality, Subdistrict Administration Organization, Bangkok Metropolitan Administration and Pattaya City according to the Act of Local Administrative Organization Decentralization Plan And Procedure Formulation B.E. 2540 (1999).

In 2003, the number of elderly people in Thailand was 399,362 persons. The government allocated the budget for subsistence allowance for each elderly in an amount of 300 Baht per month totaled 1,437,703 million Baht per year by allocate 300 Baht per one elderly through his life. Initially, Local Administrative Organization shall implemented acceding to the regulation of the Department of Public Welfare concerning the subsistence allowance for the elderly B.E. 2543 (2000) which was repealed later.

Regarding a survey, rearrange and approve a name list of the eligible elderly for subsistence allowance, the Department of Local Administration regulated Municipality and Subdistrict Administration Organization to implement a Regulation of the Ministry of Interior on the Administration of the Allowance for the Elderly by the Local Administrative Organizations B.E. 2548 (2005) and Cabinet Decision on 12 December 2006 concerning increasing the Allowance for the Elderly from 300 Baht to 500 Baht per one elderly through his life. In accordance with Elderly Person Act, B.E. 2546 (2003) and a Resolution of Board of the Elderly No. 4/2552 (2009) on 21 May 2009, the government declared the Ministry of Interior on the Administration of the Allowance for the Elderly by the Local Administrative Organizations B.E. 2552 (2009)

On 23 August 2011, the government specified an urgent policy of step-up monthly allowance for elderly aged 60-69 
years will receive 600 Baht, 70-79 years will receive 700 Baht, $80-89$ years will receive 800 Baht and over 90 years will receive 1,000 Baht per month. Lately, Cabinet Decision on 18 October 2011 approved for step-up monthly allowance for elderly from budget year 2011 onwards.

\section{PROBLEMS OF THE POLICY OF SUBSISTENCE ALLOWANCE}

The study found that the problem is divided into 2 parts as follows:

1. Problem from client

1.1 Most of societies in Thailand are rural societies. Residences of most elderly generally locate out of town or far away from service of government. Travelling to receive the service from the government encounter many troubles and difficulties. For these reasons lead to an ignorance against the policy of the elderly.

1.2 Lack of participation from the elderly, due to lack of enthusiasm of receiving the service caused from bodily state or lack of interesting in the policy.

1.3 The elderly do not realize that they are eligible for subsistence allowance caused from ignorance of the elderly or lack of sufficient public relation from government sections.

1.4 The elderly fails to submit the application within the time limit. For this policy, the elderly shall submit the application together with the evidence required namely identical card or other documents which shows the photo of document holder issued by the government together with its photocopy, house registration together with its photocopy and bank account together its photocopy if the applicant desires to receive the allowance through bank account, for these reasons lead to delay in process.

1.5 The elderly do not receive the allowance from their representative. In case the elderly cannot receive the allowance by themselves, they are able to appoint someone through the power of attorney to receive the allowance on behalf of them. Generally, most of grantee (representative) will their relatives or acquaintance and the elderly do not receive the allowance from such persons.

1.6 Sometime, in case the elderly is dead and relatives of elderly fails to inform his death to the authority, the name of elderly still be in the allowance system.

\section{Problem from service provider or the policy}

2.1 Selection the eligible elderly to receive the allowance is not considered other facts. The eligible elderly shall has the only following qualification: aged over 60 years, Thai nationality and domiciled in civil database of Local Administrative Organization, not be the person who receive the welfare or other benefits from the government sectors, State Enterprises or Local Administrative Organization. Therefore, other facts such as health or income problem do not be brought to consider as a criterion of selection.

2.2 Lack of sufficient public relation from government sections, this lead to elderly do not know the news and rarely to register to receive the allowance.
2.3 Changing several times of payment method. Presently, the payment for allowance is able to pay directly to eligible by means of cash or bank transfer.

2.4 Lack of specific government sectors from Local Administrative Organization who is responsible for the allowance. Present, the responsible sector is under supervision of the Chief Administrator of the Subdistrict Administration Organization.

2.5 The Subdistrict Administration Organization still lack of the authority who graduated from this field of work such as Social Welfare Worker or Social Worker. Mostly, the officer the Subdistrict Administration Organization Office who is responsible for this field of work is general administrative officer.

2.6 Lack of sufficient budget to support for subsistence allowance. The large number of elderly caused insufficient budget of Administration Organization.

\section{RECOMMENDATIONS}

The study found that recommendations to solve the problems concerning elderly subsistence allowance are identified as follows:

1. Local Administrative Organization should stipulate additional criterion for selection and should bring other aspects of problems such as income and/or health problems to the consideration of the committee.

2 The Authority should make a payment for subsistence allowance within the time limit. Presently, some government sectors do not make a payment within the time limit, for example, one payment per two months or one payment per three months. Therefore, each month, the Authority should specify the exactly period of payment.

3. The government should promote the profession to the elderly in order to expand an opportunity to increase their income.

4. The government should set up the elderly club or association in each community or district in order to publicize the project and promote the profession or provide a recreation for the elderly for the purpose to avoid their stress which may lead to health problem in long term.

5. Government sectors or Local Administrative Organization should give an advice or consult concerning health risk and welfare to the elderly.

6. The Government should not restrict or specify the hospital to receive a treatment. The elderly should have a right to receive the treatment in every hospital; in addition, government should provide the medical team to provide a medical service in rural areas

A conclusion section is not required. Although a conclusion may review the main points of the paper, do not replicate the abstract as the conclusion. A conclusion might elaborate on the importance of the work or suggest applications and extensions.

\section{CONCLUSION}

Problems found in the policy of subsistence allowance for 
the elderly are caused both in service provider and client. The most important problem is lack of budget to support the policy; furthermore, lack of mutual effective communication between service provider and client. Therefore, the policy provider should publicize the policy and increase a communication with client.

\section{REFERENCES}

[1] Sujira Mali, Problems and guideline for the development of elderly social welfare service of the local administrative organizations in Chattrakan District, Phitsanulok Province. Uttaradit Rajabhat University, August 2014

[2] Sudarat Sudsomboon, Social Welfare for Aging People in Thailand. Southern Technology Magazine Year 7 Issue 1, Thaksin University, January-June 2014.

[3] Sudarat Sudsomboon, Social Welfare for Aging People in Thailand. Southern TechnologApichai Bowornmot, Problems of the management of cost of living for the Elders of Phothong Sub-District Administration Organization, Selaphum District, Roi-Et Province. Rajaphat Maha Sarakham University, 2010 Magazine Year 7 Issue 1, Thaksin University, January-June 2014.

[4] Witit Trinteeyakul, The Intervestigation of the problems and Service Demand in Social Welfare of The Senior Citizens Banchang Sub district Administrative Organization at Banchang District in rayong Province. Khon Kaen University, 2007.

[5] Theerapat Deekaew, Health Problems and Welfare Needs of the Elderly in Boonruang Sub District Municipality, Chiangkhong District, Chiangrai Province. Khon Kaen University, 2008.

[6] Krirksak Ploypichai, Problems and Social Service Needs of Senior Citizens in Takong Sub District Administrative Organization in Muang District of Nakhonpathom Province. Khon Kaen University, 2010.

[7] Kritsada Saimetha, Performance and Problems and Obstacles regarding the Elderly Welfare Service of Wangmaprangnuea Sub District Administrative Organization, Wangwiset District, Trang Province. Khon Kaen University, 2009.

[8] Tawanna Aa-saa-moon, The Problem State of Arrangements for the Elderly's Social Welfare by the Saimoon Sub District Administration Organization, SawangDaendin District, Sakonnakhon Province. Sakonnakhon Rajabhat University, 2013.

[9] Jutamas Kaewchuenchai, Problems And Guidelines On The Implementation Of Elderly Welfare Services Of Huaymonthong Subdistrict Administrative Organization, Kamphaeng Saen District, Nakhon Pathom Province. Faculty of Humanities and Social Sciences, Nakhon Pathom Rajabhat University, 2014.

[10] Thailand Development Research Institute, To one and all social welfare in 2017. Thai Health Promotion Foundation, March 2011.

[11] Thanachai Soonthorn-anantachai, The Equality, Equity and Social Justice with the Social Welfare of Thailand. Academic Journal.

[12] Pondchai Jaiperm, The problem of civil society for the elderly allowance a study of Bangkhontee District, Samutsongkram Province. Khon Kaen Uviversity, 2008.

[13] Yupin Peunpa, Problems and obstacles in operating the elderly living allowance project of Phromphiram Sub-District Administrative Organization (SAO), Phrom Phiram District, Phitsanulok Province. Khon Kaen Uviversity, 2010.

[14] Rumpa Peamkamoljit, Problems of allowance provision for the elderly of Chiang Mai Munivipality. Chiang Mai University, 2011.

[15] Thitirath Reungjam, Problems and Obstacles of the project of the subsistence allowance for the elderly: A case study of Phrasamutchedi subdistrict municipality, Phrasamutchedi district, Samutprakarn Province. Boorapha University, 2011.

[16] Yongyut kanthajit, Problem situations and solutions of the public service on the senior citizens' subsidy districbution in the Local Administration Organization of Mae Suay District, Chiangrai Province. Chiangrai Rajabhat University, 2011.

[17] Marayat Maiman, Problems in Remitting the Pension for the Elderly People of Chok-Chai Sub-district Municipality, Doi Luang District, Chiangrai Province. Chiangrai Rajabhat University, 2012.
[18] Changwat Phatthalung, Problems and obstacles in receiving the elderly living allowance of Lan Khoi Subdistrict Municipality, Amphoe Pa Phayom. Khonkaen University, 2009. 